\title{
Staff perceptions of organisational values in a large South African manufacturing company: exploring socio-demographic differences
}

\begin{abstract}
Authors:
Nico Martins ${ }^{1}$

Melinde Coetzee ${ }^{1}$

Affiliations:

${ }^{1}$ Department of Industrial and Organisational

Psychology, University of

South Africa

Correspondence to:

Melinde Coetzee

Email:

coetzm1@unisa.ac.za

Postal address:

PO Box 392, UNISA 0003,

South Africa

Dates:

Received: 11 Feb. 2011

Accepted: 25 Aug. 2011

Published: 14 Nov. 2011

How to cite this article: Martins, N., \& Coetzee, M. (2011). Staff perceptions of organisational values in a large South African manufacturing company: exploring socio-demographic differences. SA Journal of Industrial Psychology/SA Tydskrif vir Bedryfsielkunde, 37(1), Art. \#967, 11 pages. http://dx.doi.org/10.4102/ sajip.v37i1.967
\end{abstract}

(C) 2011. The Authors. Licensee: AOSIS OpenJournals. This work is licensed under the Creative Commons Attribution License.
Orientation: Companies' concerns about increasing their competitiveness, responsiveness and adaptability in a globalised, highly complex and turbulent business environment have led to a renewed interest in the role of corporate values and culture in improving organisational effectiveness and performance.

Research purpose: The objective of the study was to explore the perceptions of men and women staff members, as well as members of various race and age groups, in a large South African manufacturing company about the current enactment of organisational values and the importance of these values.

Motivation for the study: The challenge of managing multi-cultural work forces from different gender, race and generational backgrounds makes an understanding of how peoples' values align with those of their organisations, as reflected in their cultures, necessary.

Research design, approach and method: Using an organisational values scale, the researchers conducted a quantitative survey on a random sample of 988 participants employed in a large South African manufacturing company.

Main findings: ANOVAs and post hoc multiple comparison of means tests revealed that gender, race and age have a significant effect on some of the dimensions of organisational values and that these biographical groups differ significantly in their perceptions of the importance of certain organisational values as well as how their organisations enact them.

Practical/mangerial implications: The findings highlight the importance of understanding staff perceptions in creating greater commitment to organisational values as important aspects of an effective organisational culture.

Contribution/value-add: This study is original research that contributes new knowledge to the field of organisational psychology and management practices.

\section{Introduction}

\section{Key focus of the study}

The emergence of a global knowledge-driven economy, international competition and an increasingly diverse workforce have increased organisations' concerns about increasing their competitiveness, responsiveness and adaptability in a highly complex and turbulent business environment (Green \& Bisseker, 2002; Weiss, 2001). These concerns have led to a renewed interest in the role of corporate culture in improving the performance and effectiveness of organisations. Weiss (2001) states that effective organisational cultures enable organisations to retain their competitive edge by adapting to, and adjusting, their changing internal and external environments.

Research has recognised organisational culture as central to organisational success (Arnold \& Randall, 2010). Trice and Beyer (1993) and Schein (1985) agree and have emphasised the importance of organisational values for assessing and understanding organisational cultures. Organisational values help employees to make sense of their environments and to direct their behaviour (Cheyne \& Loan-Clarke, 2009).

Another prominent trend in organisations is to focus on attracting and retaining staff from all demographic groups in order to improve workforce performance and to improve their competitive position (Torrington, Hall, Taylor \& Atkinson, 2009). For example, Welbourne, Cycyota and Ferrante (2007) found that gender diversity in top management teams had a direct association 
with organisations' financial performance. The challenge of managing multi-cultural work forces from different gender, race and generation backgrounds has led to a renewed interest in understanding how people's values align with those of organisations as reflected in their cultures. The fit or misfit between individual and organisational values is essential to an effective and functioning organisational culture (Weiss, 2001). Recent research on value cognisance suggests that when employees have work values that match those of their organisations they tend to be satisfied with their jobs, show commitment and identify with their organisations. In addition, retention rates are significantly higher (Amos \& Weathington, 2008).

This research sets out to explore the perceptions of men and women staff members as well as members of different race and age groups in a large South African manufacturing company about how the company currently enacts its organisational values and the importance the employees attach to these values. Rollinson (2005) states that the attention organisations give to culture and value surveys as a way of predicting employees' commitment to, and satisfaction with, their organisations is one of the most prominent trends in organisations today.

\section{Background to the study}

The effectiveness of an organisation's culture is often a function of the values and beliefs employees of the organisation hold (Luthans, 2011; Weiss, 2001). The consistency that results from shared values and beliefs provides a basis for coordinated and planned organisational action. Culture is a key medium through which organisations build best practices. Specific practices (like planning, work design, making decisions and resolving conflicts) affect performance and effectiveness. Similarly, organisational cultural effectiveness is a function of converting core corporate values and beliefs into policies and practices consistently. According to Brown (2011), a strong, widely internalised corporate culture is frequently the reason for the success of companies, like 3M, Google, and Disney. Organisational culture often determines the way policies and best practices are communicated, understood, and accepted or rejected (Weiss, 2001).

The focus of the present study is the dominant culture of the organisation that represents the core values that most employees of the organisation share. The core values of the organisation are those concepts or beliefs that are relevant to desirable end-states or behaviours. They transcend situations and guide selection and evaluations of behaviour and events (Kreitner \& Kinicki, 2010, p. 66). The dominant organisational culture is a system of shared meaning that employees hold. It distinguishes the organisation from other organisations. The dominant organisational culture gives an organisation its distinct personality (Hoffman \& Jones, 2005). The sharedmeaning aspect of culture makes it a potent device for guiding and shaping behaviour.
In a strong organisational culture, employees value the organisation's core values and share them. High attachment to, or acceptance of, the organisation's core values lead to higher levels of commitment and results in a stronger and more effective organisational culture because of the high degree of sharedness (Schneider, Salvaggio \& Subirats, 2002). According to Robbins and Judge (2011), a strong organisational culture reduces employee turnover because it demonstrates high agreement about what the organisation represents. Such unanimity of purpose builds cohesiveness, loyalty and organisational commitment.

Because of the importance attached to the organisation's culture, managers are often concerned with how employees perceive the characteristics of an organisation's culture, of which their perceptions of the actual enactment of the espoused organisational values are core aspects (Robbins \& Judge, 2011). Whereas espoused values represent the explicitly stated values and norms that the organisation prefers, enacted values represent the values and norms that the organisation actually exhibits or converts into employee behaviour (Kreitner \& Kinicki, 2010). According to Chatman and Jehn (1994), characterising an organisation's culture according to its central values requires it to identify a range of relevant values and then to assess how strongly employees hold and share them.

In a sample of United States firms, O'Reilly, Chatman, and Caldwell (1991) identified seven dimensions of organisational culture:

1. innovative

2. stable

3. respectful of people

4. outcome-orientated

5. detail-orientated

6. team-orientated

7. aggressive.

Interestingly, these dimensions are similar to those of Hofstede and colleagues (1990), which they generated from an international sample of firms. The dimensions that Chatman and Jehn (1994) developed resemble two of the four types of cultural knowledge that Sackmann (1992) found generalised across a single organisation. After conducting canonical correlations, their research showed similar factor patterns in the firms they studied. It seems that innovation, stability, an orientation toward people, an orientation toward outcomes or results, an emphasis on being easygoing, attention to detail and a collaborative or team orientation are pervasive themes in organisational culture. In summary, studies a number of researchers conducted (Chatman \& Jehn, 1994; O'Reilly, Chatman \& Caldwell, 1991; Xenikou \& Furnham, 1996) show that seven primary characteristics seem to capture the essence of an organisation's culture and which organisational values and norms generally express. Table 1 shows that these include innovation and taking risk, attention to detail, outcome orientation, people orientation, team orientation, aggressiveness and stability (Robbins \& Judge, 2011). 
Appraising an organisation using these characteristics gives a composite picture of the organisation's culture. This picture becomes the basis for the perceptions and feelings of shared understanding that employees have about the organisation, how it does things and how it expects employees to behave. These characteristics often mix to create highly diverse organisations. For example, the managers of a company may encourage and reward taking risks and change. Managers may pride themselves on its history of experimenting with new technologies and its success in regularly introducing innovative products. The company encourages managers or employees, who have good ideas, to 'run with them'. It treats failures as learning experiences. The company may pride itself on being market-driven and being able to respond rapidly to the changing needs of its customers. Managers may focus on high productivity but believe that they will achieve this by empowering and developing the company's employees. They may design job activities around teams and encourage team members to interact with people with different functions and at different levels of authority. They may give employees considerable autonomy to choose how to achieve goals. The company may promote the health and safety of its employees and encourage ethical and responsible behaviour (Robbins \& Judge, 2011).

\section{Trends from the literature}

\section{Organisational values}

In the context of the present study, the construct 'organisational values' refers to some of the deep-level diversity characteristics that people share. They are important factors for shaping people's mindsets about their organisational lives. Demographics tend to reflect a surface-level diversity that points to differences in easily perceived characteristics (like gender, race, ethnicity, age or disability). However, deep-level diversity characteristics reflect what people think and feel about their organisations, work environments, jobs and careers. Deep-level diversity characteristics become progressively more important for determining similarities within groups as people get to know one another better (Robbins \& Judge, 2011). When group

TABLE 1: Overview of culture characteristics organisations often use to express core organisational values.

\begin{tabular}{ll}
\hline Characteristic & Description \\
\hline Innovation and taking risk & $\begin{array}{l}\text { The degree to which they encourage employees to be } \\
\text { innovative and take risks. }\end{array}$ \\
Attention to detail & $\begin{array}{l}\text { The degree to which they expect employees to show } \\
\text { precision, analysis and attention to detail. }\end{array}$ \\
Outcome orientation & $\begin{array}{l}\text { The degree to which managers focus on results } \\
\text { or outcomes rather than on the techniques and } \\
\text { processes employees use to achieve them. }\end{array}$ \\
People orientation & $\begin{array}{l}\text { The degree to which managers consider the effect } \\
\text { of the outcomes of their decisions on the people in } \\
\text { organisations. }\end{array}$ \\
Team orientation & $\begin{array}{l}\text { The degree to which managers organise work } \\
\text { activities around teams rather than individuals. }\end{array}$ \\
Aggressiveness & $\begin{array}{l}\text { The degree to which people are aggressive and } \\
\text { competitive rather than easygoing. }\end{array}$ \\
Stability & $\begin{array}{l}\text { The degree to which organisational activities } \\
\text { emphasise maintaining the status quo rather than } \\
\text { growth. }\end{array}$ \\
\hline
\end{tabular}

Note: Table adapted from Robbins, S.P., \& Judge, T.A. (2010). Essentials of Organizational behaviour. (10th edn). Boston: Pearson. members agree about work values, they will develop a strong culture and reach value consensus using visible similarities between group members (Mannix, Thatcher \& Jehn, 2001).

Organisations subscribe to a constellation of core values and one profiles them according to these values. This enables managers to determine whether the organisations' values are consistent and support their corporate goals and initiatives. In addition, organisations are less likely to achieve their corporate goals when employees perceive an inconsistency between the espoused (explicitly stated) values and the behaviours the organisations think are important for accomplishing their goals (Kreitner \& Kinicki, 2010). Therefore, managers try to reduce the gaps between the espoused and enacted organisational values because they can significantly influence employee attitudes and organisational performance. For example, a study that Kaptein (2008) conducted showed that employees were more likely to behave ethically when managers behaved in a way that set a good ethical example and when they kept their promises and retained their commitment. In addition, Amos and Weathington (2008) reported that overall individualorganisational value congruence affects satisfaction with organisations as entities, employees' job satisfaction, affective and normative commitment and turnover.

Furthermore, research by Grossman (2009) showed that differences between employees' perceptions of discrepancies between the enacted and espoused organisational values affected employees' performance and turnover. Here, cultural fit or employee perception surveys help managers to determine the match between enacted and espoused organisational values. One can use the results of these surveys to improve work environments and to align organisations' espoused values with their enacted values and norms (Grossman, 2009; Kreitner \& Kinicki, 2010). Employees' perceptions of how organisations enact their espoused organisational values relate also to the organisational climate (Robbins \& Judge, 2011). James and colleagues (2008) see organisational climate as the team spirit or psychological climate at organisational level because it represents the shared perceptions of the employees of organisations and their work environments. Research by Carr, Schmidt, Ford and DeShon (2003) found that psychological climates relate strongly to employees' levels of job satisfaction, involvement, commitment and motivation.

Research has shown that people's values differ because of generation and gender (Weiss, 2001). The advent of organisational subcultures with differing values may weaken and undermine organisations if they conflict with their dominant cultures and / or overall objectives. This emphasises the importance of paying attention to how employees from different race, gender and age groups perceive the enactment and importance of the espoused organisational values (Luthans, 2011; Martins \& Von der Ohe, 2006). Therefore, the researchers will test the hypothesis that follows empirically:

- Hypothesis 1: Men and women staff members, and members from different race and age groups, differ significantly in their perceptions of the values the 
organisation is currently enacting and in how they perceive the importance of these values.

\section{Research objective}

The broad purpose of this study was to explore employee perceptions of the organisational values a large South African manufacturing company is currently enacting and of how important its employees see these values. More specifically, the study aimed to assess whether men and women staff members, and members of various race and age groups, differed significantly in their perceptions of the company's organisational values. With a younger generation entering the South African workforce, along with the changing demographic profile of race and gender groups that employment equity legislation has caused, this study is important. It is also important to recognise that, although the social context of organisations create and sustain their organisational cultures, they are dynamic and constantly evolving (Brooks, 2009).

This seems to suggest an ongoing challenge for organisations to stay in touch with their employees' perceptions of their cultures and values. Furthermore, the increasing challenge of aligning diverse groups of people in the multi-cultural South African organisational context to organisations' business strategies and goals for sustained competitiveness and survival, gives this research continued importance.

\section{The potential value of the study}

The findings of this study may contribute valuable new knowledge that organisations may use to inform organisational interventions that aim to improve the effectiveness of organisational cultures in order to increase overall performance and effectiveness.

\section{Research design}

\section{Research approach}

The researchers followed a quantitative survey design with primary data to achieve the research objectives.

\section{Research method}

\section{Participants}

The researchers chose a random sample of 1270 from a population of 3500 employees in a large South African manufacturing company in Gauteng province for the study. The final sample consisted of 988 participants who yielded usable questionnaires. This is a response rate of $78 \%$. In terms of racial composition, the sample consisted of $71 \%$ White persons and 29\% Black persons (21\% African people, $3 \%$ Coloured people and 5\% Indian people). The participants comprised $77 \%$ men and $23 \%$ women. The participants were predominantly in their early or establishment career life stages. Sixty-seven per cent were between the ages of 21 and $45,33 \%$ were between 46 and 60 or 60 and above (in their middle to late career life stages).

\section{Measuring instrument}

The researchers used an organisational values scale (OVS) for the present study. The company that participated in the study initially developed the OVS (with the assistance of external experts in the field) for its internal use. The external experts ensured the content validity of the questionnaire by assessing the contents of the questionnaire to ensure that it covered the theory of the domain adequately whilst internal experts verified that the questionnaire aligned with the value needs the organisation expressed.

Exploratory factor analyses on a sample of 2500 employees confirmed the validity and reliability of the instrument (Martins \& Coetzee, 2009). The researchers used two different criteria to determine the number of dimensions (values) they should extract for the value scales. These were the scree test and the latent root criteria (eigenvalues $>0.40$ ).

Inspection of the scree test showed that there is a change in direction after the eight value dimensions of the values scale. Based on the cumulative percentage of eigenvalues, it was decided to retain eight dimensions (values), which accounted for $40.22 \%$ of the total variance, and an additional value dimension. Together with the eight dimensions, they accounted for $43.58 \%$ of the total variance (Martins \& Coetzee, 2009). Based on the exploratory factor analyses by Martin \& Coetzee (2009), the revised version of OVS was used to achieve the objectives of the present study.

Table 2 shows that high internal consistency reliabilities (ranging between 0.84 and 0.95 ) were obtained for the sample of employees who participated in the study. This shows that the internal consistency (reliability) of the OVS (Martins \& Coetzee, 2009) and the extracted values (dimensions) are consistent in what they intend to measure.

TABLE 2: Organisational Values Scale (OVS) - internal consistency reliability of sub-scales $(n=988)$.

\begin{tabular}{lc}
\hline Organisational Values Scale dimensions & Cronbach's alpha coefficient \\
\hline Currently enacted values & \\
Empowered to grow and contribute & 0.94 \\
Performance monitoring & 0.92 \\
Ethical and responsible behaviour & 0.90 \\
Alignment to business strategy & 0.90 \\
Health and safety & 0.93 \\
Responsible self-development & 0.86 \\
Risk and innovation & 0.84 \\
Teamwork & 0.86 \\
Importance of values & \\
Empowered to grow and contribute & 0.95 \\
Performance monitoring & 0.93 \\
Ethical and responsible behaviour & 0.92 \\
Alignment to business strategy & 0.92 \\
Health and safety & 0.97 \\
Responsible self-development & 0.86 \\
Risk and innovation & 0.86 \\
Teamwork & 0.94 \\
Problem solving & 0.90 \\
\hline
\end{tabular}


The OVS (Martins \& Coetzee, 2009) uses two 4-point Likert scales to measure employees' perceptions of how frequently they observe the currently enacted values in the organisation and how important the employees regarded them. The scales that measured the frequency were 'seldom' (or $<25 \%$ ), 'not often' (or $<50 \%$ ), 'regularly' (or $>50 \%$ ) and 'mostly' (or $>75 \%$ ) whilst the scales that measured the importance of those values to the employees were 'not important', 'slightly important', 'important' and 'very important'.

The OVS (Martins \& Coetzee, 2009) is a self-rated, multifactorial measure. It consists of nine sub-scales for measuring the currently enacted values and the importance of the values. Descriptions of the various sub-scales follow.

Empowered to grow and contribute (fourteen items): This relates to questions about employees' and leaders' attitudes towards, and behaviour about, developing the skills and competencies they need to perform their jobs and providing the necessary support and guidance.

Performance monitoring (eight items): This relates to questions about employees' and leaders' attitudes towards, and behaviour about, taking accountability for tracking their own and others' performance and results, providing feedback and encouraging others to perform and develop the skills they need to deliver results.

Ethical and responsible behaviour (eight items): This relates to questions about employees' and leaders' attitudes towards, and behaviour about, behaving in an ethical and responsible manner towards others in the organisation as well as honouring and respecting the organisation's values, goals, rules and regulations, policies and procedures.

Alignment to business strategy (seven items): This relates to questions about employees' and leaders' attitudes towards, and behaviour about, ensuring that they understand and align their personal and teams' goals to the business strategy and goals of the organisation.

Health and safety (five items): This relates to questions about employees' and leaders' attitudes towards, and behaviour about, taking responsibility for their own and the safety of others by promoting health and safety and addressing unsafe and unhealthy working processes, behaviours and actions.

Responsible self-development (seven items): This relates to questions about employees' and leaders' attitudes towards, and behaviour about, taking responsibility for one's selfdevelopment, seeking feedback from others, developing new skills and seeking out and providing growth and development opportunities.

Risk and innovation (four items): This relates to questions about employees' and leaders' attitudes towards, and behaviour about, seeking and implementing breakthrough ideas and approaches and being committed to excellence and innovation.
Teamwork (four items): This relates to questions about employees' and leaders' attitudes towards, and behaviour about, adhering to and supporting team objectives and codes of behaviour, contributing actively to the team and engaging members, communicating openly and treating members with respect by sharing relevant knowledge and information with members

Problem solving (four items): This relates to questions about employees' and leaders' attitudes towards, and behaviour about, understanding problems, finding best solutions, sharing insights and implementing the best ideas.

\section{Research procedure}

The researchers followed an electronic survey approach. Ethical clearance and permission to conduct the study were obtained from the managers of the organisation that participated in the study. The managers informed the relevant employees of the purpose of the study. Participation was voluntary. This procedure ensured that the employees participated of their own free will and allowed participants to complete the electronic survey in their own time. This may have increased the possibility that they answered the questionnaires honestly.

Comprehensive instructions and details about confidentiality and the purpose of the questionnaire were provided to all the participants. Because of the possible sensitive nature of the study (participants reported on their attitudes and feelings about the organisation), the data collection method used seemed appropriate because the participants could complete the questionnaires anonymously. Written consent was obtained and the participants were informed to complete a consent form. The participants who completed and returned the questionnaires and consent forms indicated that they had granted permission for the researchers to use their questionnaires for research purposes.

The researchers were available to answer questions and address any concerns. They maintained the confidentiality of the participants and kept completed questionnaires secure. The participants who wanted feedback provided their contact information and received feedback about the results of the study.

\section{Data analysis}

The Statistical Package for the Social Sciences (SPSS, 2008) was used to analyse the data. Cronbach's Alpha coefficients were used to assess the internal consistency of the measuring instrument. ANOVAs and several post hoc comparisons of means tests were conducted to test the research hypothesis. The biographical groups of gender, race and age were treated as the independent variables and the OVS dimensions as the dependent variables. A cut-off point of $p \leq 0.05$ was set for interpreting the statistical significance of the results. 


\section{Results}

\section{Perceptions of the currently enacted organisational values}

Table 3 gives the results of the analysis of variance for the perceived currently enacted organisational value dimensions and Table 6 reports the means and standard deviations. They show that race had a significant effect on the OVS variables of performance monitoring, health and safety as well as risk and innovation. Whilst race and gender had a significant effect on teamwork, gender had a significant effect on ethical and responsible behaviour.

Table 4 shows that Indians perceived the current enactment of the values of performance monitoring, risk and innovation as significantly less positive than the White and African participants did. Similarly, the Indian and Coloured participants perceived the current enactment of the values for health and safety as significantly less positive than the White and African participants did

An interesting observation is that age had no significant effect on the OVS current enactment of value dimensions.

\section{Perceptions of the importance of organisational values}

With regard to the importance of values, Table 3 shows that race had a significant effect on alignment with the business strategy. Race and gender had a significant effect on teamwork, ethical and responsible behaviour, responsible self-development and problem solving. Table 6 reports the means and standard deviations. Race and age had a significant effect on being empowered to grow and contribute as well as on health and safety. Table 4a shows that the White and Coloured participants perceived the values for responsible self-development as less important than did the African participants. The African and White participants perceived the values for health and safety as significantly more important than the Coloured participants did. The White participants perceived the values of teamwork as significantly less important than the African participants did.

With regard to age, Table $4 \mathrm{~b}$ shows that the participants aged between 31 and 45 perceived the values of health and safety and being empowered to grow and contribute as being significantly less important than did their older counterparts (those between 46 and 59).

Table 5 shows that the women participants perceived the values of ethical and responsible behaviour, responsible self-development, teamwork and problem solving as significantly more important than did the men participants. The results provide evidence for Hyptohesis 1 (men and women staff members, and members from the different race and age groups, differ significantly in their perceptions of the currently enacted organisational values and of their importance), which was accepted.

\section{Discussion}

Organisational culture and employee perception surveys are important ways of assessing the match between enacted and espoused organisational values. Organisations can use the results of these surveys to improve the work environment and increase the effectiveness of the organisational culture

TABLE 3: Organisational Values Scale- ANOVA summary of the significance of race, gender and age groups on Organisational Values Scale dimensions $(n=988)$.

\begin{tabular}{|c|c|c|c|c|c|c|}
\hline OVS dimension & $\begin{array}{l}\text { Source (biographical } \\
\text { group) }\end{array}$ & Type III ss & $d f$ & $\mathrm{~ms}$ & $F$ & $p$ \\
\hline \multicolumn{7}{|l|}{ Currently enacted values } \\
\hline Performance monitoring & Race & 1386.01 & 3 & 462.00 & $4.17 * *$ & 0.01 \\
\hline Ethical and responsible behaviour & Gender & 316.99 & 1 & 316.99 & $4.71^{*}$ & 0.03 \\
\hline Health and safety & Race & 1510.39 & 3 & 503.46 & $5.22 * * *$ & 0.001 \\
\hline Risk and innovation & Race & 1765.44 & 3 & 588.48 & $4.93 * *$ & 0.002 \\
\hline \multirow[t]{2}{*}{ Teamwork } & Gender & 522.07 & 1 & 522.07 & $5.57^{*}$ & 0.02 \\
\hline & Race & 706.04 & 3 & 235.35 & $2.51^{*}$ & 0.05 \\
\hline \multicolumn{7}{|l|}{ Importance of values } \\
\hline \multirow[t]{2}{*}{ Empowered to grow and contribute } & Race & 696.12 & 3 & 232.04 & $2.94 *$ & 0.03 \\
\hline & Age & 693.16 & 3 & 231.05 & $2.93^{*}$ & 0.03 \\
\hline \multirow[t]{2}{*}{ Teamwork } & Gender & 598.65 & 1 & 598.65 & $10.32 * * *$ & 0.00 \\
\hline & Race & 909.03 & 3 & 303.01 & $5.22 * * *$ & 0.00 \\
\hline Health and safety & Race & 1114.47 & 3 & 371.49 & $3.74^{* *}$ & 0.01 \\
\hline \multirow[t]{2}{*}{ Ethical and responsible behaviour } & Gender & 507.18 & 1 & 507.18 & $9.19 * * *$ & 0.00 \\
\hline & Race & 521.22 & 3 & 173.74 & $3.15^{*}$ & 0.02 \\
\hline \multirow[t]{2}{*}{ Responsible self-development } & Gender & 540.55 & 1 & 540.55 & $8.58^{* * *}$ & 0.00 \\
\hline & Race & 1552,78 & 3 & 517.59 & $8.22 * * *$ & 0.00 \\
\hline Alignment to business strategy & Race & 1057.91 & 3 & 352.64 & $3.30 *$ & 0.02 \\
\hline \multirow[t]{2}{*}{ Problem solving } & Gender & 572.91 & 1 & 572.91 & $8.89 * * *$ & 0.00 \\
\hline & Race & 625.21 & 3 & 208.40 & $3.23 *$ & 0.02 \\
\hline
\end{tabular}

ss, sum of squares; $d f$, degrees of freedom; $\mathrm{ms}$, mean square; $F$, F-statistic, $p$, probability value.

${ }_{*}^{*}, p<0.05$

$*^{* * *}, p<0.01$ 
TABLE 4a: Summary of Scheffé Multiple Significant Mean Comparison tests ( $n=988):$ Race.

\begin{tabular}{|c|c|c|c|}
\hline (I) Race & (J) Race & $\begin{array}{l}\text { Mean } \\
\text { Difference } \\
(I-J)\end{array}$ & $\begin{array}{l}\text { Significance at } \\
p \leq 0.05\end{array}$ \\
\hline \multicolumn{4}{|c|}{$\begin{array}{l}\text { OVS: Currently enacted values - } \\
\text { performance monitoring }\end{array}$} \\
\hline White & Indian & 5.5867 & $*$ \\
\hline African & Indian & 4.9046 & $*$ \\
\hline Indian & White & -5.5867 & $*$ \\
\hline Indian & African & -4.9046 & $*$ \\
\hline \multicolumn{4}{|c|}{$\begin{array}{l}\text { OVS: Currently enacted values - } \\
\text { health and safety }\end{array}$} \\
\hline White & Indian & 4.4239 & $*$ \\
\hline White & Coloured & 6.5138 & $*$ \\
\hline Indian & White & -4.4239 & $*$ \\
\hline Coloured & White & -6.5138 & $*$ \\
\hline \multicolumn{4}{|c|}{$\begin{array}{l}\text { OVS: Currently enacted values - } \\
\text { risk and innovation }\end{array}$} \\
\hline White & Indian & 6.5979 & $*$ \\
\hline African & Indian & 6.1377 & $*$ \\
\hline Indian & White & -6.5979 & $*$ \\
\hline Indian & African & -6.1377 & $*$ \\
\hline \multicolumn{4}{|c|}{$\begin{array}{l}\text { OVS: Importance of values - } \\
\text { responsible self-development }\end{array}$} \\
\hline African & White & 2.5543 & $*$ \\
\hline African & Coloured & 5.4589 & $*$ \\
\hline White & African & -2.5543 & $*$ \\
\hline Coloured & African & -5.4589 & $*$ \\
\hline \multicolumn{4}{|c|}{$\begin{array}{l}\text { OVS: Importance of values - } \\
\text { health and safety }\end{array}$} \\
\hline African & Coloured & 7.8822 & * \\
\hline White & Coloured & 6.7252 & * \\
\hline Coloured & African & -7.8822 & * \\
\hline Coloured & White & -6.7252 & $*$ \\
\hline \multicolumn{4}{|c|}{$\begin{array}{l}\text { OVS: Importance of values - } \\
\text { teamwork }\end{array}$} \\
\hline African & White & 1.9118 & $*$ \\
\hline White & African & -1.9118 & $*$ \\
\hline
\end{tabular}

Note: Source of significant difference effects: race and age groups

OVS, Organisational Values Scale.

I denotes group, a standard notation used in the statistical formula to compare several means of groups.

$\mathrm{J}$ denotes group, a standard notation used in the statistical formula to compare several means of groups.

TABLE 4b: Summary of Scheffé Multiple Significant Mean Comparison tests $(n=988):$ Age.

\begin{tabular}{llll}
\hline (I) Age & (J) Age & $\begin{array}{l}\text { Mean } \\
\text { Difference } \\
\text { (I-J) }\end{array}$ & $\begin{array}{l}\text { Significance at } \\
p \leq 0.05\end{array}$ \\
\hline $\begin{array}{l}\text { OVS: Importance of values - } \\
\text { health and safety }\end{array}$ & & \\
$\begin{array}{l}\text { 46-59 yrs } \\
\text { 31-45 yrs }\end{array}$ & $31-45$ yrs & 1.9771 & $*$ \\
$\begin{array}{l}\text { OVs: Importance of values - } \\
\text { empowered to grow and contribute }\end{array}$ & $46-59$ yrs & -1.9771 & $*$ \\
$46-59$ yrs & $31-45$ yrs & 1.8309 & $*$ \\
$31-45$ yrs & $46-59$ yrs & -1.8309 & $*$ \\
\hline
\end{tabular}

Note: Source of significant difference effects: race and age groups

OVS, Organisational Values Scale.

I denotes group, a standard notation used in the statistical formula to compare severa means of groups.

J denotes group, a standard notation used in the statistical formula to compare several means of groups.

(Grossman, 2009; Robbins \& Judge, 2011; Kreitner \& Kinicki, 2010). Table 7 shows that the perceptions of the race groups especially, followed by the gender groups, had a significant effect on a number of the organisational value dimensions. The perceptions of the age groups had a significant effect on the importance of only two of the organisational value dimensions (being empowered to grow and contribute as well as health and safety).

These findings seem to corroborate the view of Koivula (2008) that different socio-demographic groups in the workplace tend to have different values. Values represent what is important to people and employees tend to bring their values to the workplace. Research has also shown that large companies tend to have sub-cultures because of occupational, professional or functional divisions and backgrounds that relate to gender, age, race, socio-economic circumstances and educational levels (Greenberg, 2005). Luthans (2011) states that organisations often overlook the importance of subcultures. Watson (2006, p. 459) defines a subculture as occurring 'where a section of an organisation follows a cultural pattern that is a variation of the main organisational pattern of measuring and values'. When such a pattern includes values that contradict the main organisational ones, one sometimes calls it a contra culture.

Sub-cultures tend to develop in large organisations to reflect common perceptions, problems, situations and experiences (Lok \& Crawford, 1999; Martins \& Coetzee, 2007; Martins \& Von der Ohe, 2006; Robbins \& Judge, 2011). According to Koivula (2008), sub-groups tend to approach organisational interactions with their own meanings and sense of priorities. In addition, for group tasks that require making decisions, judgement and creativity, the type of homogeneity that value similarity amongst employees creates may actually inhibit performance. On the other hand, when all groups share the importance of organisational values, this often increases achievement motivation, communication, knowledge sharing and teamwork (Koivula, 2008).

Koivula (2008) suggests that it is more advisable to align employees to a core set of common values that all share instead of trying to change the values of an organisation's employees. It is important to recognise the different perceptions of staff members from the various race, gender and age groups in a company. Differences in perceptions often reflect the unique needs, problems and experiences of these sub-groups (Martin \& Von der Ohe, 2006). This may weaken the overall organisational culture as well as affect overall organisational performance and effectiveness (Robbins \& Judge, 2011).

The present study suggests that the Indian participants feel more negative than do the White and African participants about the way the organisation monitors performance. Monitoring performance means monitoring the attitudes to, and behaviour of, employees and leaders when they accept accountability for tracking their own and others' performance, providing feedback and encouraging others to develop the skills they need to deliver results. The Indian participants seem to perceive monitoring behaviour that relates to risk and innovation (seeking and implementing breakthrough 
TABLE 5: Summary results - Bonferroni (Dunn) t-test for significant mean differences (gender) $(n=988)$.

\begin{tabular}{|c|c|c|c|}
\hline Bonferroni $t$-grouping & Mean & $N$ & $\begin{array}{l}\text { Gender } \\
\text { group }\end{array}$ \\
\hline \multicolumn{4}{|c|}{$\begin{array}{l}\text { OVS : Currently enacted organisational values - } \\
\text { ethical and responsible behaviour }\end{array}$} \\
\hline A & 90.80 & 196 & Women \\
\hline B & 89.02 & 792 & Men \\
\hline \multicolumn{4}{|c|}{$\begin{array}{l}\text { OVS : Currently enacted organisational values - } \\
\text { teamwork }\end{array}$} \\
\hline A & 89.87 & 196 & Women \\
\hline B & 88.05 & 792 & Men \\
\hline \multicolumn{4}{|c|}{$\begin{array}{l}\text { OVS : Importance of organisational values - } \\
\text { ethical and responsible behaviour }\end{array}$} \\
\hline A & 90.10 & 196 & Women \\
\hline B & 88.30 & 792 & Men \\
\hline \multicolumn{4}{|c|}{$\begin{array}{l}\text { OVS : Importance of organisational values - } \\
\text { responsible self-development }\end{array}$} \\
\hline A & 85.94 & 196 & Women \\
\hline B & 84.15 & 792 & Men \\
\hline \multicolumn{4}{|c|}{$\begin{array}{l}\text { OVS : Importance of organisational values - } \\
\text { teamwork }\end{array}$} \\
\hline A & 87.08 & 196 & Women \\
\hline B & 85.24 & 792 & Men \\
\hline \multicolumn{4}{|c|}{$\begin{array}{l}\text { OVS : Importance of organisational values - } \\
\text { problem solving }\end{array}$} \\
\hline A & 88.59 & 196 & Women \\
\hline B & 86.97 & 792 & Men \\
\hline \multicolumn{4}{|c|}{$\begin{array}{l}\text { Minimum significant difference: } 1.26 ; p \leq 0.05 \\
N \text {, number; OVS, Organisational Values Scale. } \\
\text { A denotes group, a standard notation used in the statistical formula to compare severa } \\
\text { means of groups. } \\
\text { B denotes group, a standard notation used in the statistical formula to compare sever } \\
\text { means of groups. }\end{array}$} \\
\hline
\end{tabular}

ideas and approaches, being committed to excellence and innovation) as less positive than do the African and White participants. Research by Eskildsen and Dahlgaard (2000) shows that leadership behaviour and management practices, which address the needs of employees for creative challenges and quality of work or life, improve employee satisfaction. The African and White participants, and those aged between 46 and 59, seem to regard health and safety as being more important than do the Coloured participants. However, the Indian and Coloured participants, and those aged between 31 and 45 , seem less positive about the enactment of the values for health and safety. The results suggest that they feel that members could take on more responsibility for promoting health and safety or addressing unsafe and unhealthy work processes and behaviour.

An interesting observation is that the women and African participants seem to regard the values associated with teamwork as being more important than do the men and White participants. The women participants also seem to attach greater value than do the men to the values associated with problem solving (making an effort to understand problems, finding the best solutions, sharing insights with others and implementing correct ideas). According to Smit and Cronje (2002), Africans relate to an Afrocentric value system whilst White people relate more to a Eurocentric value system. The Afrocentric value system relates to a more 'feminine culture' that emphasises nurturing, the commonality of all people,

TABLE 6: Organisational Values Scale biographical groups - means and standard deviations of significant mean differences $(n=988)$.

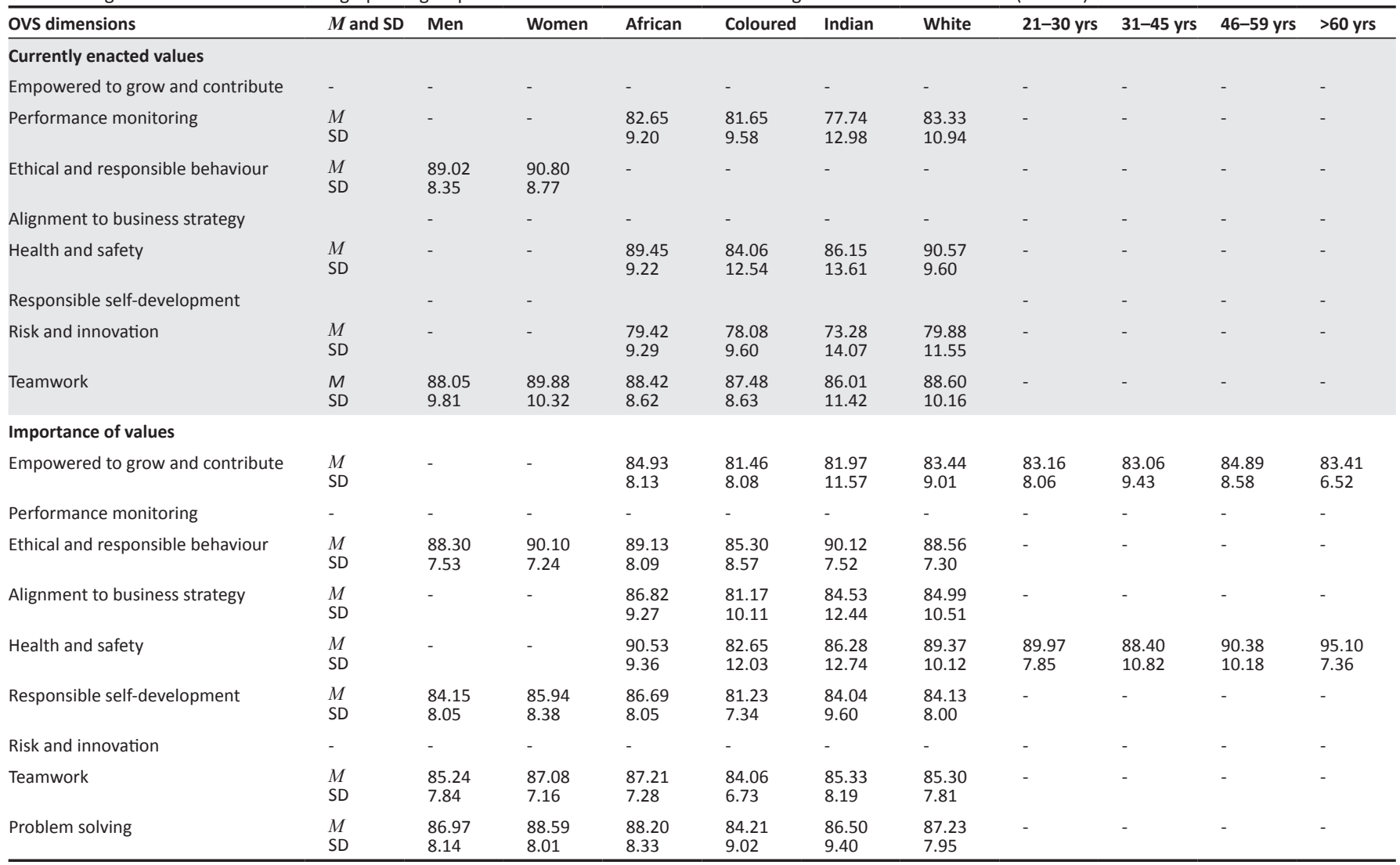

$M$, mean; SD, standard deviation. 
shared vision and values, communal efforts as well as a concern for relationships and the living environment. The Eurocentric value system relates to a more 'masculine culture' and is more concerned about achieving material success, position and rewarding individual merit. Assertiveness, ambition and competitiveness characterise the Eurocentric culture.

Campion, Medsker and Higgs (1993) found a positive and significant correlation between employee satisfaction and communication as well as cooperation between work groups. They also found positive and significant correlations between employee satisfaction and workload sharing as well as between employee satisfaction and social support. The differences between the various race groups seem to agree with research that Martins and von der Ohe (2006) conducted on subcultures in the South African context. Their findings indicate that race groups tend to experience organisational cultural dimensions differently and that they tend to modify their values to reflect their own situations and needs. The women and African participants also seem to attach greater importance than do the men and White participants to the values of responsible self-development. This refers to taking responsibility for one's self-development, seeking feedback from others, developing new skills and seeking growth and development opportunities.

The participants in the establishment phase of the life or career ( 46 to 59 years old) seem to attach greater importance to the values of being empowered to grow and contribute. This value relates to developing the skills and competencies they need to perform their jobs and receiving the necessary support and guidance. One could attribute this to the rapidly changing technological developments, which may cause skills and competencies to become obsolete, and the concerns of people about continued employability (Schreuder \& Coetzee, 2011).

With regard to gender, the research findings on gender differences indicate that gender is a moderator in employeeattitude research (Kidd \& Smewing, 2001; Smith, Smits \& Hoy, 1998). Their findings suggest a positive linear relationship between supervisor support and commitment for women in particular. Women also have a greater need for emotionally supportive work environments as a source of career satisfaction (Nabi, 2001). Research by Eskildsen and Dahlgaard (2000) showed that an organisation could improve employee satisfaction by focusing on improving organisational performance in issues like leader behaviour, management practices and processes that increase employee feelings and perceptions of empowerment, involvement, recognition and growth opportunities.

An interesting observation is that the women participants seem to attach greater value to the enactment of ethical and responsible behaviour. This value relates to behaving in an ethical and responsible manner towards employees as well as honouring and respecting the values, goals, rules, regulations, policies and procedures of organisations. On the other hand, the men participants perceived enacting these behaviours as less positive than did the women. According to Weiss (2001), organisational culture has a pervasive influence on the ethical behaviour of all and leaders set the moral tone. Maak and Pless (2006) agree and state that ethical and responsible behaviour requires leadership that cultivates a work environment where diverse people find meaning, feel respected, recognised and included (not discriminated against or harassed) and where they are able to contribute to their potential in a business and moral sense.

\section{Limitations and recommendations}

Future investigations should consider some of the limitations of this study. Firstly, because the present study was limited to participants in a single company in the manufacturing industry, one cannot generalise the findings to other economic sectors.

TABLE 7: Summary overview of the effect of significant differences in the biographical groups on the organisational value dimensions.

\begin{tabular}{|c|c|c|c|}
\hline $\begin{array}{l}\text { Organisational Values Scale } \\
\text { dimension }\end{array}$ & $\begin{array}{l}\text { Biographical } \\
\text { group }\end{array}$ & $\begin{array}{l}\text { Highest and } \\
\text { lowest mean } \\
\text { scores }\end{array}$ & Significance \\
\hline \multicolumn{4}{|l|}{ Currently enacted values } \\
\hline Empowered to grow and contribute & \multicolumn{3}{|c|}{ No significant differences } \\
\hline Performance monitoring & Race & $\begin{array}{l}\text { White and } \\
\text { African (H) } \\
\text { Indian (L) }\end{array}$ & $* *$ \\
\hline Ethical and responsible behaviour & Gender & $\begin{array}{l}\text { Women }(H) \\
\text { Men }(L)\end{array}$ & $*$ \\
\hline Alignment to business strategy & \multicolumn{3}{|c|}{ No significant differences } \\
\hline Health and safety & Race & $\begin{array}{l}\text { White }(\mathrm{H}) \\
\text { Coloured and } \\
\text { Indians (L) }\end{array}$ & $* * *$ \\
\hline Responsible self-development & \multicolumn{3}{|c|}{ No significant differences } \\
\hline Risk and innovation & Race & $\begin{array}{l}\text { White and } \\
\text { African (H) } \\
\text { Indians (L) }\end{array}$ & $*$ \\
\hline \multirow[t]{2}{*}{ Teamwork } & Gender & $\begin{array}{l}\text { Women }(H) \\
\text { Men }(L)\end{array}$ & $*$ \\
\hline & Race & $\begin{array}{l}\text { Source not } \\
\text { detected }\end{array}$ & $*$ \\
\hline \multicolumn{4}{|l|}{ Importance of values } \\
\hline Empowered to grow and contribute & $\begin{array}{l}\text { Race } \\
\text { Age }\end{array}$ & $\begin{array}{l}\text { Source not } \\
\text { detected } \\
46-59(\mathrm{H}) \\
31-45(\mathrm{~L})\end{array}$ & $\begin{array}{l}* \\
*\end{array}$ \\
\hline Performance monitoring & \multicolumn{3}{|c|}{ No significant differences } \\
\hline Ethical and responsible behaviour & $\begin{array}{l}\text { Gender } \\
\text { Race }\end{array}$ & $\begin{array}{l}\text { Women }(\mathrm{H}) \\
\text { Men }(\mathrm{L}) \\
\text { Indians }(\mathrm{H}) \\
\text { Coloured }(\mathrm{L})\end{array}$ & $\begin{array}{l}* * * \\
*\end{array}$ \\
\hline Alignment to business strategy & Race & $\begin{array}{l}\text { Source not } \\
\text { detected }\end{array}$ & $*$ \\
\hline Health and safety & $\begin{array}{l}\text { Race } \\
\text { Age }\end{array}$ & $\begin{array}{l}\text { African and } \\
\text { White (H) } \\
\text { Coloured (L) } \\
46-59(\mathrm{H}) \\
31-(\mathrm{L})\end{array}$ & $\begin{array}{l}* * \\
* *\end{array}$ \\
\hline Responsible self-development & $\begin{array}{l}\text { Gender } \\
\text { Race }\end{array}$ & $\begin{array}{l}\text { Women }(\mathrm{H}) \\
\text { Men }(\mathrm{L}) \\
\text { Africans }(\mathrm{H}) \\
\text { Coloured and } \\
\text { White (L) }\end{array}$ & $\begin{array}{l}* * * \\
* * *\end{array}$ \\
\hline Risk and innovation & \multicolumn{3}{|c|}{ No significant differences } \\
\hline Teamwork & $\begin{array}{l}\text { Gender } \\
\text { Race }\end{array}$ & $\begin{array}{l}\text { Women }(H) \\
\text { Men }(L) \\
\text { Africans (H) } \\
\text { Whites }(L)\end{array}$ & $\begin{array}{l}* * * \\
* * *\end{array}$ \\
\hline Problem solving & $\begin{array}{l}\text { Gender } \\
\text { Race }\end{array}$ & $\begin{array}{l}\text { Women }(H) \\
\text { Men }(L) \\
\text { Source not } \\
\text { detected }\end{array}$ & $\begin{array}{l}* * * \\
*\end{array}$ \\
\hline
\end{tabular}

$\mathrm{H}$; highest mean score; L, lowest mean scores.

$*, p<0.05$

$* * *, p<0.001$ 
Secondly, given that White participants and men dominated the sample, a more balanced sample would have contributed more meaningful insights about the socio-demographic differences between the race, gender and age groups. It is recommended that participants from various organisations and occupational contexts, and a more demographically diverse group, are used in future studies to obtain a more representative sample.

Thirdly, longitudinal studies are needed to validate the differences between the various socio-demographic groups the researchers observed in this study. Although the social context of an organisation creates and sustains an organisation's culture, it is dynamic and constantly evolving (Brooks, 2009).

In the context of employment equity and affirmative action, researchers should examine, both theoretically and empirically, the constructs that are relevant to the present study, as well as other psychological constructs, to yield broader conclusions about how the socio-demographic characteristics of employees influence their perceptions of the enactment of the core organisational values espoused in the dominant organisational culture.

\section{Conclusions and implications for practice}

Given that employment equity and affirmative action have contributed to a more demographically diversified workforce in South African workplaces, one can conclude that the findings of the present study added valuable new knowledge that organisations can use to inform their organisational practices concerned with creating strong organisational cultures for sustained effectiveness. Organisations can use the findings when designing interventions aimed at achieving a greater match or better fit between the core values of the dominant organisational culture and its staff members.

\section{Acknowledgements Competing interests}

The authors declare that they have no financial or personal relationship(s) that may have inappropriately influenced them in writing this paper.

\section{Authors' contributions}

Prof. N. Martins was responsible for the project and assisted with writing up the research. Prof. M. Coetzee was responsible for collecting the data, analysing the statistics and assisted with writing up the research.

\section{References}

Amos, E.A., \& Weathington, B.L. (2008). An analysis of the relation between employee-organization value congruence and employee attitudes. Journal of Psychology: Interdisciplinary and Applied, 142(6), 615-631. http://dx.doi. org/10.3200/JRLP.142.6.615-632, PMid:19049240

Arnold, J., \& Randall, R. (2010). Work psychology: Understanding human behaviour in the workplace. (5th edn). Harlow, Essex: Pearson Education.

Brooks, I. (2009). Organisational behaviour. London: Pearson.
Brown, D.R. (2011). An experiental approach to organizational development. (8th edn). Boston: Pearson

Campion, M.A., \& Medsker, G., \& Higgs, C. (1993). Relations between work group characteristics and effectiveness: Implications for designing effective work groups. Personnel Psychology, 46(4), 823-850. http://dx.doi.org/10.1111/j.1744-6570.1993. tb01571.x, http://dx.doi.org/10.1111/j.1744-6570.1993.tb01571.x

Carr, J.Z., Schmidt, A.M., Ford, J.K., \& DeShon, R.P. (2003). Climate perceptions matter: a meta-analytic path analysis relating molar climate, cognitive and affective states and individual level work outcomes. Journal of Applied Psychology, 88, 605-619. http://dx.doi.org/10.1037/0021-9010.88.4.605, PMid:12940402

Chatman, J.A., \& Jehn, K.A. (1994). Assessing the relationship between industry characteristics and organizational culture: How different can you be? Academy of Management Journal, June, 522-553. http://dx.doi.org/10.2307/256699

Cheyne, A., \& Loan-Clarke, J. (2009). Organisational and corporate culture. In T. Redman \& A. Wilkinson (Eds.), Contemporary human resource management, (pp. 243-275). London: Pearson.

Eskildsen, J.K., \& Dahlgaard, J.J. (2000). A causal model for employee satisfaction. Total Quality Management, 11(8), 1081-1094. http://dx.doi. org/10.1080/095441200440340, PMCid:2860396

Green, P., \& Bisseker, C. (2002). A new bottom line for companies: sustainable development. Financial Mail, 166(2), 22-23.

Greenberg, J. (2005). Managing behaviours in organizations. Singapore: Pearson Education.

Grossman, R.J. (2009). Hiring to fit the culture. HR Magazine, February, 41.

Hoffman, D.A., \& Jones, L.M. (2005). Leadership, collective personality, and performance. Journal of Applied Psychology 90(3), 509-522. http://dx.doi. org/10.1037/0021-9010.90.3.509,PMid:15910146

Hofstede, G., Neuijan, B., Ohayv, D., \& Sanders, G. (1990). Measuring organizational cultures: A qualitative and quantitative study across twenty cases. Administrative cultures: A qualitative and quantitative study across twenty cases. Admit
Science Quarterly, 35, 286-316. http://dx.doi.org/10.2307/2393392

James, L.R., Choi, C.C., Ko, C.E., McNeil, P.K., Minton, M.K., Wright, M.A., \& Kim, K. (2008). Organisational and psychological climate: a review of theory and research. European Journal of Work and Organizational Psychology, 17(1), 5-32. http:// dx.doi.org/10.1080/13594320701662550

Kaptein, M. (2008). Developing and testing a measure for the ethical culture of organisations: The corporate ethical virtues model. Journal of Organizational Behavior, 1, 923-047. http://dx.doi.org/10.1002/job.520

Kidd, J.M., \& Smewing, C. (2001). The role of the supervisor in career and organizational commitment. European Journal of Work and Organisational Psychology, 10(1), 25-40. http://dx.doi.org/10.1080/13594320042000016

Kreitner, R., \& Kinicki, A. (2010). Organizational behaviour. (9th edn). New York: McGraw-Hill.

Koivula, N. (2008). Basic human values in the workplace. Helsinki: University of Helsinki.

Lok, P.S., \& Crawford, J. (1999). The relationship between commitment and organizational culture, sub-culture leader style and job satisfaction in organisationa change and development. Leadership and Organization Development Journal, 20(7), 365-373. http://dx.doi.org/10.1108/01437739910302524

Luthans, F. (2011). Organizational behaviour: an evidence-based approach. New York: McGraw-Hill.

Maak, T., \& Pless, N.M. (2006). Responsible leadership in a stakeholder society a relational perspective. Journal of Business Ethics, 66, 99-115. http://dx.doi. org/10.1007/s10551-006-9047-z

Martins, N., \& Coetzee, M. (2009). Living the values survey: Exploratory factor analysis of the Organisational Values Scale. Unpublished Research Report, Department of Industrial and Organisational Psychology, University of South Africa.

Martins, N., \& Coetzee, M. (2007). Organisational culture, employee satisfaction, perceived leader emotional competency and personality type: An exploratory study of a South African engineering company. SA Journal for Human Resource Management, 5(2), 20-32.

Martins, N., \& Von der Ohe, H. (2006). Detecting sub-cultures in an organisation. Southern African Business Review, 10(2), 130-149.

Mannix, E.A., Thatcher, S., \& Jehn, K.A. (2001). Does culture always flow downstream? Linking group consesnsus and organizational culture. In C.L. Cooper, S. Cartwright \& P.C. Earley, The International Handbook of Organizational Culture and Climate. (pp. 290-306), Chichester: John Wiley \& Sons.

Nabi, G.R. (2001). The relationship between HRM, social support and subjective career success among men and women. International Journal of Manpower, 22(5), 457-471. http://dx.doi.org/10.1108/EUM0000000005850

O'Reilly, C.A., Chatman, J., \& Caldwell, D.F. (1991). People and organizational culture: A profile comparison approach to assessing person-organization fit. Academy of Management Journal, September, 487-516.

Robbins, S.P., \& Judge, T.A. (2011). Organizational behaviour. (13th edn). Upper Saddle River: Pearson.

Robbins, S.P., \& Judge, T.A. (2010). Essentials of Organizational behaviour. (10th edn). Boston: Pearson.

Rollinson, D. (2005). Organisational behaviour and analysis: An integrated approach London: Prentice-Hall.

Sackmann, S. (1992). Culture and subcultures: An analysis of organizationa knowledge. Administrative Science Quarterly, 37, 140-161. http://dx doi. org/10.2307/2393536 
Schein, E.H. (1985). Organizational culture and leadership. San Francisco: Jossey-Bass. Schneider, B., Salvaggio, A.N., \& Subirats, M. (2002). Climate strength: a new direction for climate research. Journal of Applied Psychology, 87, 220-229. http://dx.doi. org/10.1037/0021-9010.87.2.220, PMid:12002951

Schreuder, A.M.G., \& Coetzee, M. (2011). Careers: an organisational perspective. (4th edn). Cape Town: Juta.

Smit, P.J., \& Cronjé, G.J. de J. (2002). Management Principles. Cape Town: Juta.

Statistical Package for the Social Sciences (SPSS). (2008). Statistical Programs for Social Sciences (SPSS): Version 17.0. SPSS Inc.

Torrington, D., Hall, L., Taylor, S., \& Atkinson, C. (2009). Fundamentals of human resource management. London: Pearson.
Trice, H.M., \& Beyer, J.M. (1993). The cultures of work organizations. Englewood Cliffs: Prentice Hall.

Watson, T.J. (2006). Organizing and managing work: organizational, managerial and strategic behavior in theory and practice. Harlow: Pearson Education.

Weiss, J.W. (2001). Organisational behaviour and change: managing diversity, crosscultural dynamics and ethics. Cincinnati: Thomson Learning.

Welbourne, T.M., Cycyota, C.S., \& Ferrante, C.J. (2007). Wall Street reaction to women in IPOs. Group and Organization Management, 32, 524-547. http://dx.doi. org/10.1177/1059601106291071

Xeniko, A., \& Furham, A. (1996). A correlation and factor analytical study of four questionnaire measures of organizational culture. Human Relations, March, 349371. http://dx.doi.org/10.1177/001872679604900305 